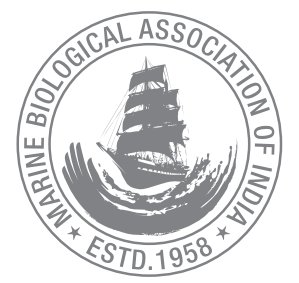

\title{
Assessment of low value bycatch and its application for management of trawl fisheries
}

\author{
A.P Dineshbabu*, Sujitha Thomas and E. Vivekanandan \\ Central Marine Fisheries Research Institute, Cochin 682018, India. \\ *Correspondence e-mail: dineshbabuap@yahoo.co.in
}

Received: 10 Jun 2014, Accepted: 30 Jun 2014, Published: 15 Oct 2014

Original Article

\begin{abstract}
The estimated annual average catch by trawlers operating from Mangalore Fisheries Harbour (southwest coast of India) was 124,105 tonnes during 2008-2011. Of the total catch, $63.9 \%$ was landed as high-value catch (HVC) for human consumption, 14.7\% as low-value bycatch (LVB), and $11.4 \%$ was discarded at sea. However, during the four years, the contribution of LVB to the trawl catch substantially increased from $2.5 \%$ to $24.6 \%$; and the discards reduced from $18.1 \%$ to $5.9 \%$. As demand for raw material from fish meal plants is increasing, trawlers are encouraged to target LVB. Trawl bycatch consisted of 205 species/groups, of which 147 were finfishes, 4 bivalves, 7 cephalopods, 21 crabs, 3 stomatopods, 3 lobsters and several miscellaneous groups. About $34 \%$ of the LVB by weight and $63 \%$ by number were juveniles of 45 commercially important species. Mapping spatio-temporal abundances of juveniles of four important demersal fish species showed that the distributions of juveniles occurred along vast coastal stretches for several months in a year. Exploitation of large quantities of juvenile and sub-adult fishes potentially contributes to growth overfishing, reduced economic returns to fisheries and loss of biodiversity; and therefore threatens the sustainable exploitation of resources. A few potential management options such as the use of bycatch reduction devices, spatial and temporal closures to trawling and fisheries refugia are discussed. Assessing the net economic value of benefits and losses due to LVB is required to achieve sustainable management of trawl fisheries.
\end{abstract}

Keywords: Fisheries bycatch, overfishing, biodiversity loss, ecosystem, fisheries sustainability

\section{Introduction}

Trawling has become one of the most efficient technological interventions in the history of marine fisheries. It has been adopted widely throughout the world and has contributed greatly to increased marine fish production. However, largely due to indiscriminate operations, bottom trawling has caused physical and ecological disturbances to the sea bottom and the ecosystem (Jennings and Kaiser, 1998). In India, the trawl fleet has contributed $51 \%$ to the marine fish landings during 2008-2012 (CMFRI, 2012). Due to intense dragging of the sea bottom and the use of very small cod-end mesh size (15 to $20 \mathrm{~mm}$ knot-to-knot), extensive damage to marine biota, including fish, along the Indian coast was recognised about 15 years ago (Devaraj and Vivekanandan, 1999). Being a relatively non-selective gear, the trawls retain most of the biota that is caught. This catch includes (i) high-value catch (HVC)- fishes, crustaceans and molluscs, which are directly used for human consumption; (ii) low-value bycatch (LVB)- not used for human consumption, but used in fish meal plants, which include juveniles of high-value fishes and adults of small-sized fishes; and (iii) discards-at-sea, which include non-edible and occasionally edible biota (Dineshbabu et al., 2013).

The demand for aquaculture feed has increased in recent years, with the proliferation of aquaculture. In India, the 
quantity of fish meal used in feed production for shrimp and carp culture in 2001 was 41,000 tonnes and 200,000 tonnes, respectively (Smith et al., 2005). Using these estimates and assuming that this trend would have continued, FAO $(2010)$ estimated the fish meal used in India to be about 270,000 tonnes by 2010. The demand for fish meal has been reflected in the emergence of a large number of fish meal plants in the country. In Karnataka (southwest coast) alone, 23 fish meal/fish oil factories with a handling capacity of 20 to 350 tonnes /day each have been registered in the last five years (Ponnuswamy et al., 2012).

The main source of raw material for these fish meal plants is the LVB from trawlers. As the demand for fish meal increased, trawlers were encouraged to target LVB. Trawlers have started to concentrate in areas of abundance of juveniles with small cod-end mesh size. This is causing significant concern regarding the sustainability of marine resources. The objectives of the present paper are to (i) quantify the volume and species composition of LVB at Mangalore Fisheries Harbour, (ii) identify areas and seasons where juveniles occur, and (iii) suggest options for reducing such bycatch.

\section{Material and methods}

Catch data on commercial bottom trawlers were collected from Mangalore Fisheries Harbour in Karnataka, southwest coast of India (Fig. 1) from 2008 to 2011.

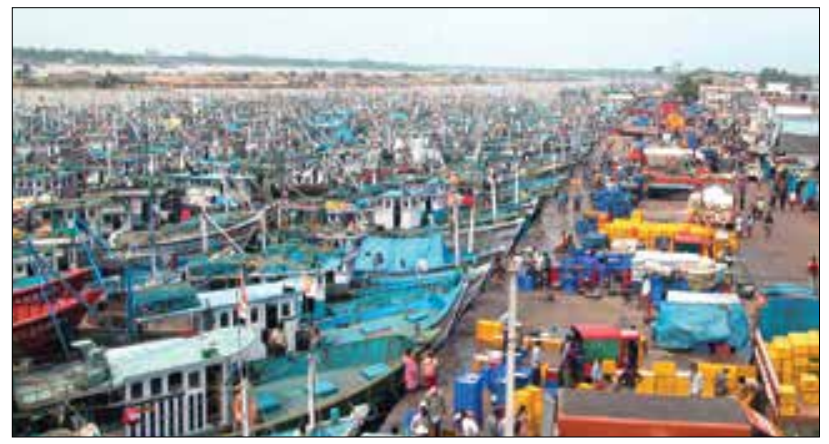

Fig. 1. Trawlers at Mangalore Fisheries Harbour

Data were collected twice a week. The catch was classified as those landed for direct human consumption, as LVB for fish meal plants, and as discards-at-sea. Monthly estimates were made on trawl effort, catch and species composition by random sampling. Along with catch data, the market prices of the two landed categories were also collected. Unsorted LVB samples were analysed to determine the juvenile composition at species level. Crew members onboard sampled trawlers collected data under the supervision of observers. Fishing crew were instructed on how to store unsorted portions of the catch, which would have been otherwise discarded. These samples were labelled, preserved in ice and stored in the fishhold. After each cruise, the preserved samples were brought to the laboratory and analysed. The geographical positions of trawling areas were noted and the data collected were used for spatial mapping of the abundance of juveniles of a few dominant species.

\section{Results}

Trawl catch: The estimated annual average catch by trawlers operating from Mangalore Fisheries Harbour was 124,105 tonnes during 2008-2011. During the four year period, the catch fluctuated by about $10 \%$ each year. Of the total catch, $63.9 \%$ was landed as high-value catch (HVC) for human consumption, 14.7\% as LVB and the remaining $11.4 \%$ was discarded at sea. However, the composition of catch in the three categories changed during the four year period. While the LVB substantially increased from $3,144 \mathrm{t}$ in 2008 to $30,737 \mathrm{t}$ in 2011, discards reduced from $22,696 \mathrm{t}$ to $7,359 \mathrm{t}$ during the same years (Fig. 2). Consequently, the contribution of LVB to the trawl catch substantially increased from $2.5 \%$ to $24.6 \%$; and the discard component decreased from $18.1 \%$ to $5.9 \%$. Surprisingly, the HVC contribution to the catch reduced by nearly $10 \%$, i.e., from $79.4 \%$ to $69.5 \%$ within the four year period (Fig. 3).

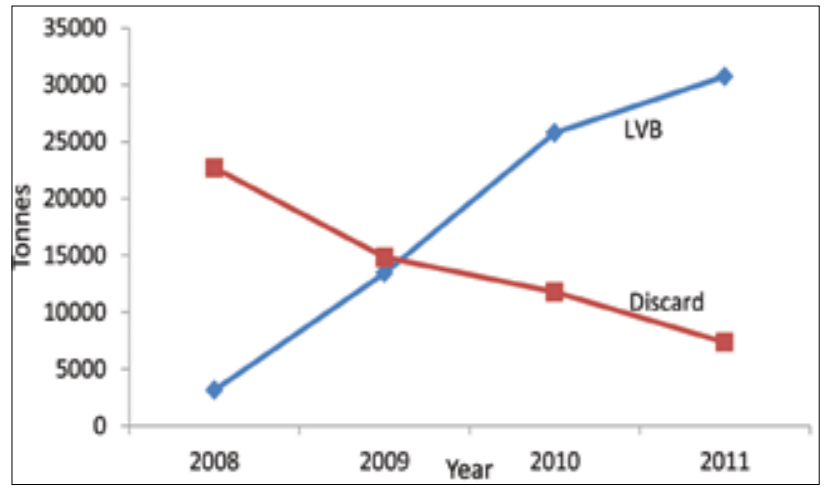

Fig. 2. Low-value bycatch and discard-at-sea by trawlers at Mangalore Fisheries Harbour

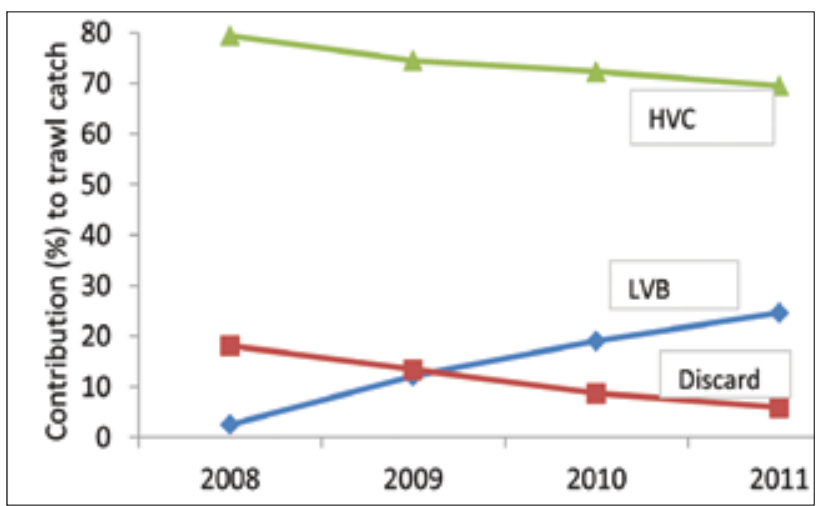

Fig. 3. Contribution of HVC, LVB and discard to trawl catch at MFH during 2008-2011 
Table 1. Composition of LVB of trawlers from Mangalore Fisheries harbour during 2008-2009; the landings are represented as annual average values.

\begin{tabular}{|c|c|c|c|c|}
\hline Species & Landing as LVB $(t)$ & Juveniles in LVB (\%) & Months of juvenile occurrence & Depth range $(\mathrm{m})$ \\
\hline Lagocephalus inermis & 994 & 50 & Nov to Apr & $10-70$ \\
\hline Sardinella longiceps & 566 & 50 & Oct to Jan & $10-50$ \\
\hline Leiognathus spp. & 558 & 50 & Oct to June & $10-60$ \\
\hline Nemipterus randalli & 483 & 100 & Sept to June & $20-170$ \\
\hline Saurida undosquamis & 458 & 80 & Sept to June & $30-90$ \\
\hline Dussumeria acuta & 369 & 80 & Sept to May & $10-50$ \\
\hline Nemipterus japonicus & 362 & 100 & Dec to May & $20-70$ \\
\hline Trichiurus lepturus & 331 & 100 & Sept to June & $10-60$ \\
\hline Saurida tumbil & 305 & 90 & Sept to June & $30-150$ \\
\hline Platycephalus spp. & 302 & 80 & Sept to June & $20-150$ \\
\hline Decapterus spp. & 277 & 80 & Sept to Nov & $16-55$ \\
\hline Lesser sardines & 225 & $50 w$ & Sept to May & $10-55$ \\
\hline Priacanthus hamrur & 173 & 90 & Sept to May & $43-150$ \\
\hline Anchovies & 110 & 20 & Jan to Apr & $10-50$ \\
\hline Eels & 101 & 50 & Oct to Dec & $20-150$ \\
\hline Cynoglossus spp. & 95 & 50 & Oct to Apr & $10-90$ \\
\hline Sepia spp. & 93 & 100 & Sept to Jan & $20-120$ \\
\hline Charybdis spp. & 86 & 100 & Sept to Mar & $20-120$ \\
\hline Epinephelus spp & 81 & 100 & Aug to Jan & $20-120$ \\
\hline Trachypenaeus sp & 70 & 50 & Nov to May & $20-50$ \\
\hline Solenocera choprai & 50 & 50 & Sept to May & $50-120$ \\
\hline Lactarius lactarius & 25 & 100 & Nov to Mar & $10-90$ \\
\hline
\end{tabular}

\section{Composition of $L V B$}

The composition of LVB was analysed during the years 2008 and 2009 and showed rich biodiversity of the trawl bycatch, constituted by 205 species/groups, of which 147 were finfishes, 4 bivalves, 7 cephalopods, 21 crabs, 3 stomatopods, 3 lobsters and several miscellaneous groups including jellyfish, sponges, sea snakes, echinoderms etc. LVB comprised a large quantity of juveniles of commercial and non-commercial fishes (Table 1). About $34 \%$ of the LVB by weight and $63 \%$ by number were juveniles of 45 commercially important species. It is estimated that annual average bycatch of juveniles of the threadfin bream Nemipterus randalli alone was 483 t by weight and about 50 million by number. Table 1 also shows that the juveniles of one species or another occurred throughout the year. The juveniles are caught from a depth range of 10 to $170 \mathrm{~m}$.

\section{Economic value of $L V B$}

The average price for LVB increased from Rs. 4/kg in 2008 to Rs. $12 / \mathrm{kg}$ in 2011 with a total value of Rs. 2.8 million $(=0.05$ million US\$) in 2011. The composition of the LVB determined the price of LVB where finfishes were in higher demand because they were better raw material for fishmeal and fish oil production. The price of the LVB occasionally went up to Rs. $16(=\$ 0.25)$ per $\mathrm{kg}$, which was more than the price of some species of fish used directly for human consumption. In 2011 , about 2,600 t of oil sardine, 1,800 t of lesser sardines and more than 32,000 t of Decapterus spp. were taken as LVB, mainly because the landing of these fishes as LVB fetched a better price. Moreover, fishes landed for human consumption have to be preserved properly in ice in the fish hold, which increases the cost and occupies the limited space available. On the other hand, the LVB is simply dumped on the deck without any preservation. Hence, the fishermen often find LVB more remunerative, especially for those categories which fetch low prices for human consumption. During seasons of high abundance of small pelagic species, there is a glut in the market of such fish, driving the fishermen to divert a part of their catches as LVB, which otherwise would have been used for human consumption.

\section{Spatial and temporal abundance of juveniles of demersal fishes}

Several demersal fishes contribute to the trawl fishery off Mangalore. As the area is also a spawning ground for many 
species, the fishing grounds are abundant with spawners, juveniles and sub-adults, leading to rich recruitment of juveniles into the fishery (Table 1). Threadfin breams are one of the major demersal fish groups, which are in demand as juveniles in the fishmeal industry as well as adults for "surimi" production (Dineshbabu and Radhakrishnan, 2009). The whitefish, Lactarius lactarius and the grouper Epinephulus diacanthus are also important commercial species off Mangalore. Analysis of spatial and temporal distributions of catches of these fishes showed that juveniles of Nemipterus

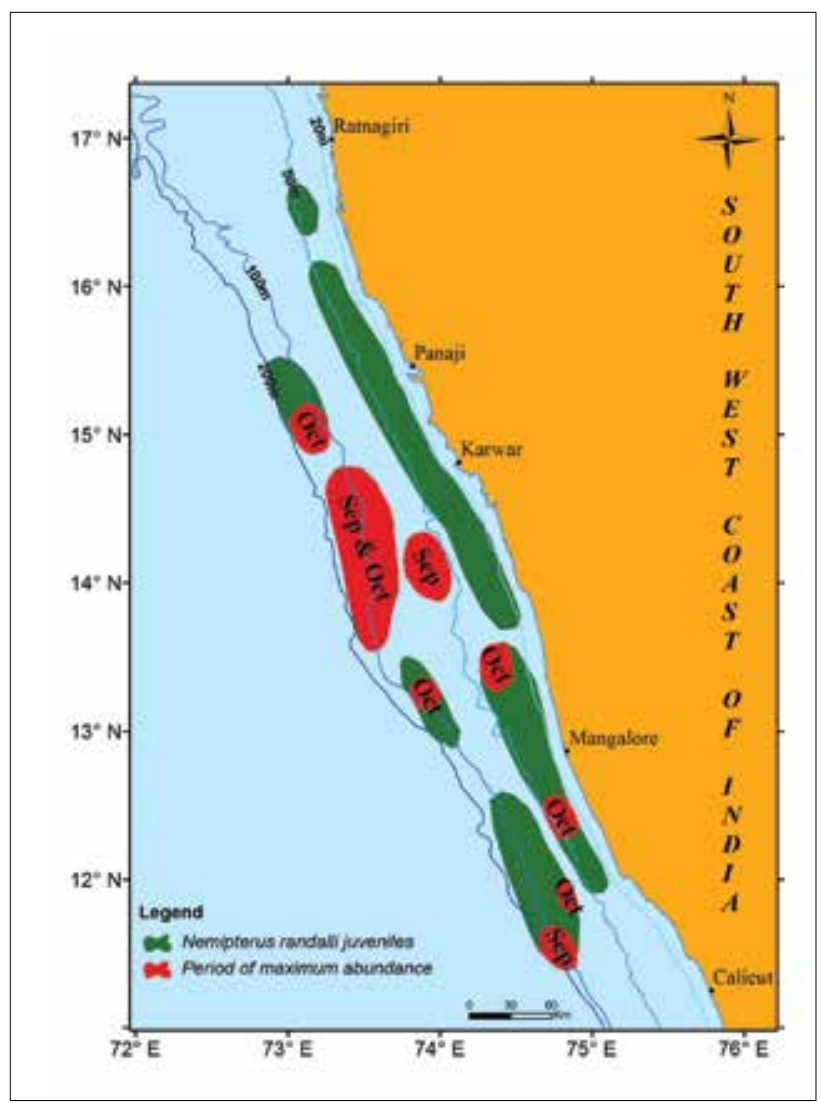

Fig. 4. Juvenile distribution of Nemiperus randalli in trawling grounds of Karnataka and their period of maximum abundance

randalli (Fig. 4) and E. diacanthus (Fig. 5) were available in large areas of the trawl fishing grounds in almost all months, whereas juveniles of $N$. japonicus (Fig. 6) and L. lactarius (Fig. 7) were restricted to smaller areas and were not observed in all months. Peak abundance of juvenile $N$. randalli was from August to October and $E$. diacanthus was during August and September. Peak juvenile abundance of $N$. japonicus and $L$. lacatrius occurred in November. In terms of vertical distribution, the juveniles of $N$. randallihad a wide distribution from $20 \mathrm{~m}$ to $170 \mathrm{~m}$ depth, $E$. diacanthus juveniles from 20 to $120 \mathrm{~m}, N$. japonicus juveniles from 20 to $70 \mathrm{~m}$, and L. lacatarius from 10 to $50 \mathrm{~m}$ depth (Figs. 4 to 7 ).

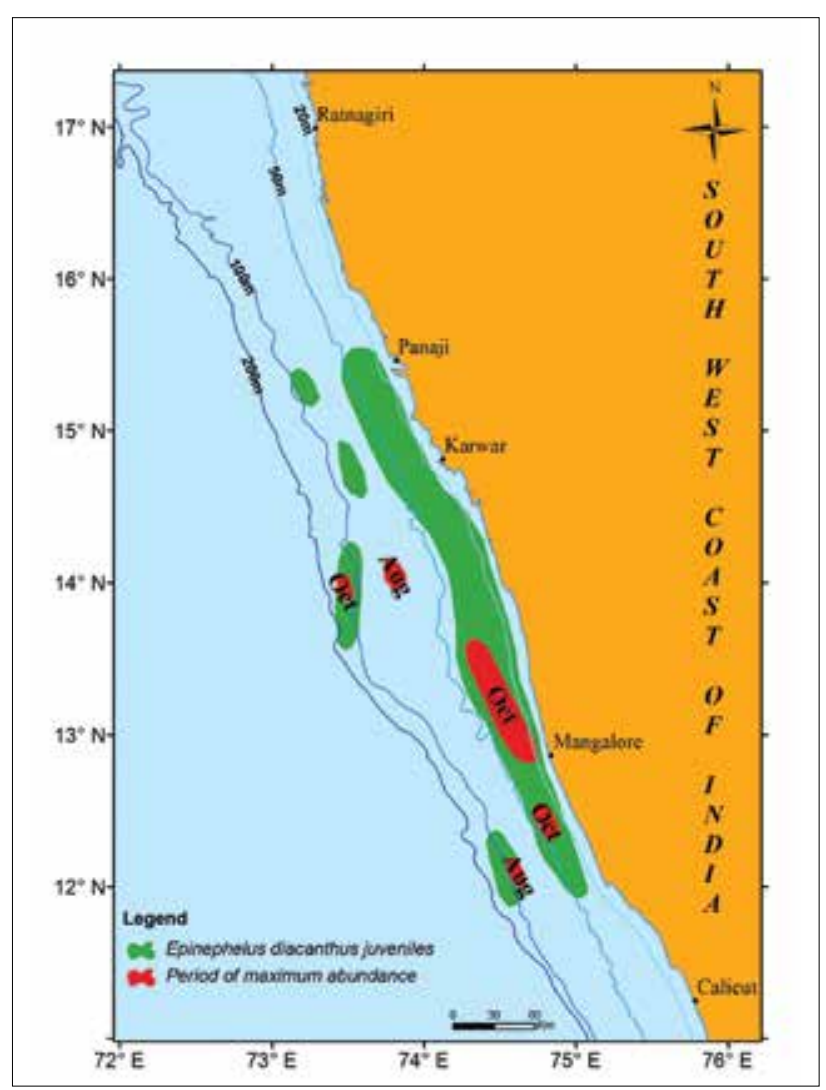

Fig. 5. Juvenile distribution of Epinephelus diacanthus in trawling grounds of Karnataka and their period of maximum abundance

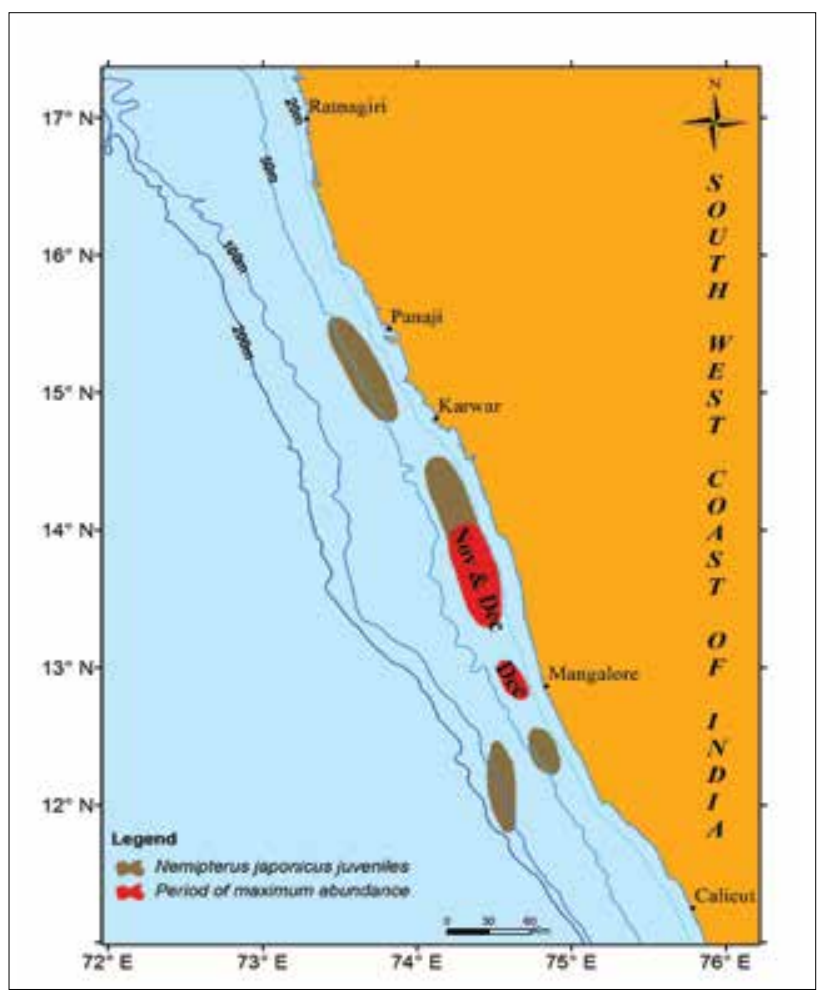

Fig. 6. Juvenile distribution of Nemipterus japonicus in trawling grounds of Karnataka and their period of maximum abundance 


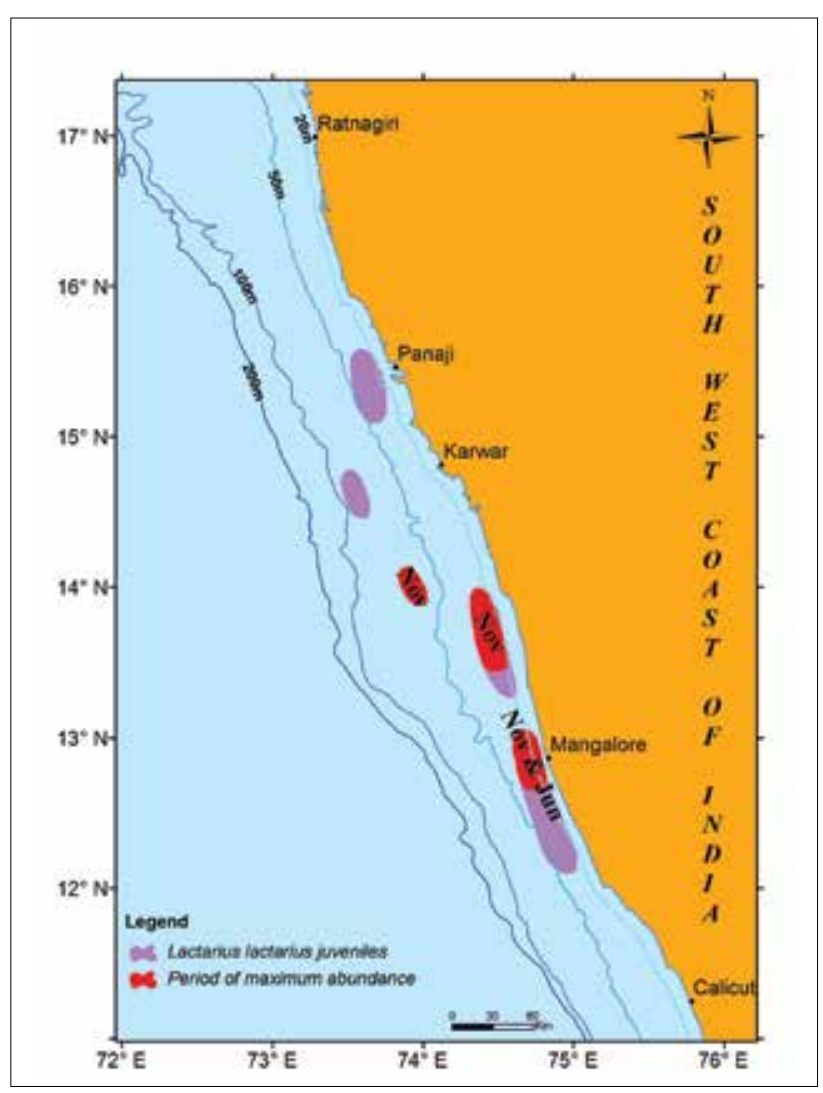

Fig. 7. Juvenile distribution of Lactarius lactarius in trawling grounds of Karnataka and their period of maximum abundance

\section{Discussion}

The volume of low value bycatch from trawlers increased substantially during 2008-2011 off Mangalore. Continuous monitoring in later years also showed that the trend continued after 2011 at Mangalore as well as along the rest of the Indian coast. Increasing demand from the aquaculture sector for protein-rich feed and a consequent better price and returns for the LVB has encouraged the trawlers to target LVB. In particular, this occurred in fishing grounds where juveniles are in greater abundance, where trawlers reduce the codend mesh size of their nets, reduce discards-at-sea, and even occasionally divert a portion of the "high-value" catch as fish meal. This situation is very different from that reported in 1999 when bottom trawlers along the Karnataka coast discarded more than 0.2 million tonnes (Menon et al., 2000). Diverting discards into LVB is also a trend observed in several other countries, especially in Asia where aquaculture is gaining importance. Alverson et al. (1994) observed that the Chinese shrimp trawl fleet discarded very little of the non-shrimp catch and all the bycatch was used as feed for the Chinese aquaculture industry. The fishery is, therefore, gradually turning into a culture-based trawl fishery. These industries, which depend on a supply of low value fish, generate significant income and jobs to local communities. While reducing discards and landing the catch is a sound strategy in one sense, targeting fishing grounds to exploit juveniles of commercially important fishes is a major concern. When exploitation targets large quantities of juvenile and sub-adult fishes, it contributes to growth overfishing, reduced economic returns from fisheries (Sathiadhas and Narayanakumar, 2002) and threatens the sustainable exploitation of resources (Dineshbabu and Radhakrishnan, 2009).

Another major cause for concern is the mortality of marine biota which is non-edible and has no commercial value. This category consists of adults of non-commercial fishes and other non-edible biota such as echinoderms, crustaceans such as stomatopods, a few species of crabs and several other invertebrates. In addition, the trawlers also interact with endangered, threatened and protected species (ETP) like corals, and charismatic species such as turtles and marine mammals. Large scale exploitation of these categories is a threat to overall biodiversity, which can have a longterm impact on the ecosystem (Thrush and Dayton, 2002; Bijukumar and Deepthi, 2006).

The estimated annual raw material requirement for the fishmeal and fish oil factories in Karnataka alone has been estimated as 200,000 tonnes (Ponnuswamy et al., 2012). While only a portion of this demand is available now, the capture and landing of LVB is likely to increase significantly in the future. Hence, it is important to implement effective measures to reduce LVB as soon as possible. Gear modifications are among the potential measures that can improve species and size selectivity of trawl nets and reduce by-catch and particularly reduce the mortality of juveniles and ETP species. In India, the Central Institute of Fisheries Technology has developed a bycatch reduction device for charismatic species as well as a juvenile fish excluder device. This device has angled metal grids and net meshes that reduce the bycatch of undersized fish and shrimps (Pravin et al., 2013). Successful use of bycatch reduction devices in many fisheries by several developed and developing countries has been reported by Kennelly (2013).

Spatial and temporal closures to trawling in areas and seasons of juvenile and spawner abundance, as well as in ecologically and biologically sensitive areas, would be another effective option to minimise bycatch. In this context, the concept of fisheries refugia deserves consideration (Paterson et al., 2012). For such a measure, however, extensive spatial and temporal maps on juvenile abundance and their habitats need to be prepared.

Any management initiative to reduce bycatch will have negative consequences on fish meal plants and other 
associated industries. Such impacts on economic and social interests will also have a strong effect on the acceptability of management measures. This is an important consideration that should be integrated into any trawl fishery management plan so that negative impacts on the fishery are minimized (APFIC, 2014). While bycatch is a driver of biodiversity loss, resource depletion and long-term economic loss to fisheries, it also helps to enhance economic benefits to trawl fishers and associated industries (even if it is for a short-term), in addition to having other social benefits such as job creation. In this context, it is important to assess the net economic value of such benefits and losses when designing an inclusive approach towards the management of trawl fisheries.

\section{References}

Alverson, D.L., M.H. Freeberg, M.H., J.G. Pope, and S.A.Murawski, 1994. A global Assessment of fisheries bycatch and discard.FAO Fish. Tech. Pap. 339, 233p

APFIC. 2014. Regional Guidelines for the Management of Tropical Trawl Fisheries in the Asian Region. Asia-Pacific Fisheries Commission, 86 pp.

Bijukumar, A. and G.R. Deepthi, 2006. Trawling and by-catch: Implications on marine ecosystem. Curr. Sci., 90: 922-931.

CMFRI, 2012. Annual Report 2011-2012. Central Marine Fisheries Research Institute, Cochin. 186p.

Devaraj, M and E. Vivekanandan, 1999. Marine capture fisheries of India: Challenges and opportunities, Curr. Sci. 76 (3):314-332.

Dineshbabu, A.P and E.V. Radhakrishnan,.., 2009. Trawl fishery of juvenile fishes along Mangalore-Malpecoast of Karnataka and its impact on fish stock. Asian Fish. Sci., 22 (2): 491-500

Dineshbabu, A.P., E.V. Radhakrisnnan, Sujitha Thomas, G. Maheswarudu, P.P. Manojkumar, A.J. Kizhakudan, S.L. Pillai, R. Chakraborty, J. Jose, P.T. Sarada, P.S. Sawant, K.K. Philipose, V.D. Deshmukh, J. Jayasankar, S. Ghosh, M. Koya, G.B. Purushottama and G. Dash, 2013. An appraisal of trawl fisheries of India with special reference on the changing trends in bycatch utilization. J. Mar. Biol. Ass. India, 52: 69-78.
FAO. 2010. The state of world fisheries and aquaculture, 2010. Food and Agriculture Organization of the United Nations, Rome, 2010, 197p.

Jennings, S. and M.J, Kaiser., 1998. The effect of fishing on marine ecosystems. Adv. Mar. Biol., 34: 201-352

Kennelly, S.J. 2013. Solving bycatch problems: successes in developed countries and challenges for protein-poor countries. In: E. Vivekanandan, Maeve Nightingale and N.M. Ishwar, (Eds), Ecosystem Approaches to the Management and Conservation of Fisheries and Marine Biodiversity in the Asia Region. Regional Symposium, Extended Abstracts, Cochin, p.123-125.

Menon, N. G., P. Nammalwar, P. U. Zacharia, and I. Jagadis, 2000. Investigations on the impact of coastal bottom trawling on demersal fishes and macrobenthos. Central Marine Fisheries Research Institute, Cochin, Annual Report 1999-2000, pp. 55-57.

Paterson, C.J., J.C. Pernetta, S. Siraraksophon, Y. Kato, N. C. Barut, P. Saikliang, O.Vibol, P. E. Chee, T.N. Nguyen, N. Perbowo, T. Yunanda, N. B. Armada, 2012. Fisheries refugia: A novel approach to integrating fisheries and habitat management in the context of small-scale fishing pressure, Ocean Coast. Manag., 33(3): 1-16.

Ponnusamy, K., K. Ambasankar and A. G. Ponniah, 2012, Production and marketing of fish meal in India - a study. Indian J. Fish. 59 (1): 147-149.

Pravin, P., T.R. Gibinkumar, S. Sabu and M.R. Boopendranath, 2013. Bycatch reduction devices. In: E. Vivekanandan, Maeve Nightingale and N.M. Ishwar, (Eds), Ecosystem Approaches to the Management and Conservation of Fisheries and Marine Biodiversity in the Asia Region. Regional Symposium, Extended Abstracts, Cochin, p. 117-120.

Sathiadhas, R. and R. Narayana Kumar, 2002. Environmental economic analysis of inshore fishery resource utilization of coastal Kerala. Final Report 2001-2002. EERC Working Paper Series: MES-3,MoEF, IGIDR, Mumbai \& World Bank.

Smith, S., E. Lindebo and D. Staples, 2005. Asian Fisheries today-The production and use of low value trash fish from marine fisheries of the Asia Pacific region, AsiaPacific fishery commission, Food and Agriculture Organization of the United Nations, RAP Publication 16, 38p.

Thrush, S. F. and P. K. Dayton, 2002. Disturbance to marine benthic habitats by trawling and dredging: Implications for marine biodiversity. Ann. Rev. Ecol. Syst., 33: 449-473. 